Volume: 11 Issue: 2 Year: 2014

\title{
Governance tools in public administration and emergent trends: Contracting, citizen participation, and networks
}

\author{
İsmail Şahin ${ }^{1}$
}

\begin{abstract}
Fragmented and complex nature of contemporary public policy problems require governments to change their traditional public administration approaches and force public administrators to provide involvement of all actors such as private firms, non-profit organizations, and citizens in policy making and implementation. In this diverse policy environment, using governance tools such as contracting out some public services, building networks, and establishing citizen participation mechanisms are considered as essential components of this new approach. Public administrators should not act as the only problem solver, but they should be facilitators in collaborative problem solving to mobilize the other actors. Along with the benefits of using these tools, there are some challenges for public administrators. Considering these difficulties, appropriate use of these tools provides public administrators to effectively address contemporary complex problems such as terrorism, drug abuse, emergency management, and healthcare crisis.
\end{abstract}

Keywords: Governance Tool, Public Administration, Contracting, Citizen Participation, Network.

\section{Introduction}

Contemporary technological developments, globalization, social differentiation, and economic restructuring have made public problems more fragmented and complex. It is widely believed that traditional government approach characterized by bureaucratic and hierarchic structure has failed to cope with these complex problems (Sehested, 2003) since "no single actor public or private, has the all - encompassing knowledge, overview, information or resources to

\footnotetext{
${ }^{1}$ Ph.D., Director of TADOC (Turkish International Academy against Drugs and Organized Crime), Turkish National Police.sahini38@hotmail.com
} 
Şahin, İ. (2014). Governance tools in public administration and emergent trends: Contracting, citizen participation, and networks. International Journal of Human Sciences, 11(2), 1082-1103. doi: 10.14687/ijhs.v11i2.2783

solve complex and diversified problems"' (Sehested, 2003 p. 89). Furthermore, 'one size fits all models' is not effective anymore in responding to highly fragmented community demands (Reddel, 2002). The limits of traditional government approach result in shift from "government" to "governance" perspective characterized by flexible, multi-centered and multi-actor systems.

Traditional government approach has been considered as the source of inefficient public policies and implementation. Herrera (2004), claims that governments have failed to provide desired outcomes in terms of policy making, implementation, and relations with citizens. Rapid and significant developments in technology, communication, and civil society have created new demands of service and made citizen expectations from governments more diversified. To effectively address contemporary complex problems such as terrorism and drug abuse, emergency management, and healthcare crisis, governments should provide involvement of all stakeholders such as private, non-profit, and citizens in policy making and implementation. In this diverse policy environment, using governance tools such as contracting out some public services, building networks, and establishing citizen participation mechanisms to incorporate the contribution of all stakeholders into the process is more likely to produce desired outcomes (Eggers and Goldsmith, 2003).

One of the emergent trends for governments is to use a smaller direct workforce to run an expanding government. Over the past two decades, governments are facing to improve public sector performance by using contractors. For example, Bush Administration attempts to launch the Yellow Pages test for the governments to apply it to all public services, which means that if governments find a service advertised in the Yellow Pages, then governments should not directly do that service themselves, but contract out. While the government services are privatized, the government becomes a hollow state, which only oversees its contractors. The hollow state is "a metaphor for the increasing use of third parties to deliver social services and generally act in the name of the state" (Milward \& Provan, 2000 p.359).

Great majority of the public policy problems are so complicated and difficult that only government organizations cannot cope with alone or find solutions to them. Private, non-profit and government organizations all can play significant roles in the public policy making and implementation (Milward \& Provan, 2000). Particularly delivering some public services such as health services, public safety, and emergency management requires partnership and integration of the organizations coming from these different sectors. Each member organization contributes to the network by using their advantages coming from being in different sectors.

Citizen participation is one of the most important concepts in public administration field. It is suggested that citizen involvement in public administration leads policy making and 
Şahin, İ. (2014). Governance tools in public administration and emergent trends: Contracting, citizen participation, and networks. International Journal of Human Sciences, 11(2), 1082-1103. doi: 10.14687/ijhs.v11i2.2783

implementation more effective and successful. Public administrators should promote deliberative democracy in which citizens can more directly participate in not only voting but also decision making and policy implementation (Abramson \& Breul \& Kamensky, 2006). They should benefit from citizens' knowledge and combine their professional and administrative knowledge with citizens' experiential and lived knowledge (Bryer, 2008; Hummel \& Stivers, 1998; Stivers, 1994). Citizens should be more participatory in the policy process because they are the ones who will live with the consequences of the decisions. They should be and view themselves as active participants in governance rather than as voters, clients, passive service receivers and customers (Bryer, 2006; Hummel \& Stivers, 1998). However, without establishing an effective participation mechanism, citizens cannot easily interact with the government and share their ideas regarding any public policy problem or project.

In this article, application of the governance tools, contracting, networks, and citizen participation in public administration field is examined. First, definition of each tool will be provided. Second, why and how governments use these tools will be discussed. Finally, the challenges facing public administrators and the implications pertaining to the use of these tools will be discussed.

\section{Contracting}

Contracting is one of the most frequently used government tools because great majority of the public agencies more or less contract for some goods and services to achieve their goals. Private sector firms often face make-or-buy decision to determine the way to produce or provide a particular products or services. Make-or-buy decision is comparing manufacturing a product to purchasing it from an outside source in terms of their costs and benefits. This is also used by public organizations to decide whether they will directly produce or product particular services or contract out.

According to Kelman (2002), contracting implies a "choice by government not to produce a product or service itself but to buy it from the outside" (p. 282). As a government tool, contracting is the practice in which a government agency contract with private sector entity for the delivery of certain products or services to government agencies or to citizens on behalf of the government. By using contracting tool, governments buy various goods and services such as weapons, planes, computers, software programs, and health care services. 
Şahin, İ. (2014). Governance tools in public administration and emergent trends: Contracting, citizen participation, and networks. International Journal of Human Sciences, 11(2), 1082-1103. doi: 10.14687/ijhs.v11i2.2783

Contracting is classified as two basic types in the literature, "procurement contracting" and “purchase-of-service contracting”. While contracting to buy products and services used directly by the government agency is called procurement contracting, contracting with third parties to deliver some government funded services to external recipients such as citizens is called purchase-ofservice contracting (Kelman, 2002).

\subsection{Why Governments Use Contracting}

Some of the primary purposes of contracting are to reduce costs, increase efficiency, improve quality and effectiveness of current services, find innovative ways of addressing new service needs, address underserved populations, and access expertise not available in-house.

The governments' failure in provision of services is considered as the primary rationale behind contracting out. It can be said that the poor performance of the government providers in the past has been one of the basic motivating factors. According to this thinking, traditional government structure and management style with hierarchical bureaucracy are inefficient in public service delivery and ineffective in responding new public service demands. Using various new market mechanisms is likely to improve efficiency and effectiveness of governments in delivering public service (Mills \& Broomberg, 1998; Kelman, 2002). Therefore, by taking advantages of market-type mechanisms, contracting enhances effectiveness and efficiency of government agencies. In addition, it provides more flexibility to redefine priorities and change operations.

\subsection{Ideal Conditions for Contracting}

Two main goal of contracting is to get good prices and good performance from the contractor firms. Three ideal conditions for contracting need to be taken into account to achieve these results: First, the work to be done by the contractor should be specified unambiguously. Tasks, results, and appropriate performance measures should be precisely specified in advance. Second, there should be competitive environment. Competitive supplier market is needed for successful contracting; therefore, it is essential to have potential providers competing with each other for lower cost and better performance. Third, the provision unit of the government should be able to monitor the contractor's performance to evaluate efficiency and effectiveness. The sufficient monitoring capability can diminish the dangers of contractor's shirking; therefore, contract administration is considered as one of the basic mechanisms of contracting (Blondal, 2005). 
Şahin, İ. (2014). Governance tools in public administration and emergent trends: Contracting, citizen participation, and networks. International Journal of Human Sciences, 11(2), 1082-1103. doi: 10.14687/ijhs.v11i2.2783

\subsection{Discussion and Implications for Public Administrators}

There are two emergent trends for governments and private sectors, affecting the extent to which contracting is used by the public sector agencies. One of the emergent trends for governments is to use a smaller direct workforce to run governments. Over the past two decades, contracting has been one of the most popular governance tools used by governments to improve public sector effectiveness. Bush Administration is using lots of contractors in Iraq. Although there are many opposing arguments about contracting with private security corporations because of the accountability and capability issues, the main intention is to make government more efficient and effective (Lawther, 2002). Martin (2001) suggests that "the role of local governments becomes one of planning, coordinating, facilitating, monitoring, and evaluating a mix of public, private, and third sector service delivery" (p. 1).

The other emergent trend is that private companies seek to create new markets in service areas traditionally reserved for the public sector. For example, Lockheed Martin won a contract to provide technology services for the Social Security Administration. Another example, Edison Inc., a New York-based education management firm, won the contracts to manage many public schools nationwide. It means that private companies created a new market in the social service and the public education areas.

Contracting may produce different results in different public service areas. Though the costs of contracting are expected to be lower than direct provision, in practice the costs may not always be as expected. There are many challenges that public administrators may face during contracting such as monitoring and managing contracts. Public administrators should know how to overcome these difficulties to effectively utilize this governance tool.

Accountability issue has become one of the most important concerns regarding contracting. Blurred boundaries between public and private sectors caused by contracting can make accountability unclear. That is, citizens and clients may be confused about who is responsible for the service and the process of service delivery and where to complain for unsatisfactory services.

Contracting with military provider firms is one of the most controversial service areas. Though military and security services have been historically considered as the core mission of government that cannot be transferred to private sectors, currently there are a lot of private security contractors providing services to the U.S. government. Majority of the debates concentrate on the military provider firms employed in the area of military operations and engaging in actual fighting in battlespaces such as Blackwater. The contractor firms, more passively engaged in actual military operation by providing logistical and technical supports such as transportation and food 
Şahin, İ. (2014). Governance tools in public administration and emergent trends: Contracting, citizen participation, and networks. International Journal of Human Sciences, 11(2), 1082-1103. doi: 10.14687/ijhs.v11i2.2783

preparation, attract less attention in this respect. Recent incidents have led government officials and citizens to be concerned about private security firms because of the lack of adequate oversight and control (Bryer, 2008). For example, a sniper working for a private security contractor killed innocent Iraqi civilians on February 27, 2007. What is the U.S. government's responsibility in this case? Scahill (2007) suggests that along with the contractor firm, the government should be responsible for unchecked and unaccountable private contractors.

For such kinds of services, the government should establish specified rules and regulations regarding engagement in the field since private contractor firms are mainly motivated by profit rather than effectiveness and accountability. However, as Milward and Provan (2000) suggest, the government agencies relying mostly on contractor providers may lack oversight expertise in governing the process.

It is important to monitor the contractor's performance to evaluate efficiency and effectiveness. Therefore, contracting should be performance-based in order "to change the behavior of contractors to focus on performance" (Martin, 2002 p. 10).However, monitoring the contractor's performance is not always easy job for the government agencies since the complex nature of some public services creates difficulties in defining and measuring performance. Particularly purchase-of-service contracting used to provide human services differs from other types of contracting in terms of target population and the nature of services. In these kinds of contracting, the difficulty in measuring performance and monitoring the contractors' activities require more government resources and efforts. For example, when the government services that aim to help disadvantage population such as homeless, mentally ill, and children are contracted out, government agency must allocate significant amount of resource to monitor and control the process of service delivery.

Governments usually respond to the inefficiencies in the government agencies by contracting the services out with private firms. However, efficiency and effectiveness of government agencies can be improved by encouraging the competition between public and private sectors to provide particular services. This is an important competitive alternative to privatizing some government services. According to Martin (1999), when public employees are allowed to compete and provided with flexibility to restructure and reengineer service delivery systems, they can successfully compete with private sectors and win these competitions. Public-private competition may be a good alternative to privatization for particular service areas that are difficult to monitor. Before privatizing some particular services, public employees should be allowed to 
Şahin, İ. (2014). Governance tools in public administration and emergent trends: Contracting, citizen participation, and networks. International Journal of Human Sciences, 11(2), 1082-1103. doi: 10.14687/ijhs.v11i2.2783

compete with the private firms to understand if the services can be efficiently provided by the public agencies.

According to Martin (2001), market model and partnership model are two different models of contracting widely used by local governments in the US. In the market model, by using competitive market pressure local governments promote competition among provider organizations for higher quality services and lower-cost service delivery. In the partnership model, local governments and private or non-profit organizations are involved in partnership arrangements in which they pool their resources and skills to efficiently and effectively provide some public services.

Managing the contracts becomes more difficult for the public administrators when the complexity of the service to be delivered is high. Some aspects of service delivery such as uncertainty about means of delivery, the degree of technical expertise required for service delivery, and the amount of training needed for the employees can increase the complexity of the services. Lawther (2002) proposes a partnership model, called Public Private Partnership, for contract administrators to overcome the challenges and achieve their goals. This model is defined as: "An arrangement of roles and relationships in which two or more public and private entities coordinate/combine complementary resources to achieve their separate objectives through joint pursuit of one or more common objectives" (Lawther, 1999 p. 33). In this concept, public administrators should work more closely with the contractors since the risk of failure is higher with high complex services.

This model introduces some changes in the way public sector staff traditionally interact with representatives of private sector firms. In this approach, public sector representatives view the other staff from contractor firms as partners in a network rather than agent in the principal-agent relationship. This may create greater opportunity for innovation and creativity in public service delivery. Public partners may be educated and trained by the private partners on some service production areas in which public sector staff needs. Cost-sharing is an important component of the partnership. Since the partnership to a large extent relies on trust between public and private actors, it can lead to an expectation of long-term commitment.

\section{Citizen Participation}

Contemporary public policy issues have become increasingly complex. For example, these problems such as limited access to health care, joblessness, and drug abuse are interconnected and require citizens to be involved in responding to these problems. Technological advances have 
Şahin, İ. (2014). Governance tools in public administration and emergent trends: Contracting, citizen participation, and networks. International Journal of Human Sciences, 11(2), 1082-1103. doi: 10.14687/ijhs.v11i2.2783

increased the speed and intensity of communications among people. Through these communication channels, people much more frequently interact with each other and their expectations from public administrators change over time. They expect public administrators to be more responsive to their needs and problems. In addition, our society has become more diverse. Because of this diversity, public administrators face challenges in responding to the demands of the people having diverse background and interests.

These changes and developments mentioned above have demonstrated that traditional public administration approach is inadequate for developing solutions to contemporary public policy problems. New approach requires public administrators to provide citizen involvement in public policy making and implementation. They should bring a diverse group of people to the table to collaboratively find solutions to complex problems since government is key partner, but not the only actor (PCI, 2006).

Citizen participation in policy making and implementation process is considered as the most distinctive characteristic of new public administration approach. Traditional public administration perspective views citizens as customer of government services. In customer concept, government agencies interact with citizens to improve quality of services. Citizens are heard by government and enable to complain of unsatisfying services. However, new approach views people as citizens participating in government decision making and policy making. In this concept, public administrators encourage and provide citizens to more directly engage in the process and promote deliberative democracy in which citizens can more directly participate in not only voting but also decision making and policy implementation that affects their lives (Abramson \& Breul \& Kamensky, 2006; Bryer and Sahin, 2012). In this participation perspective, people engage in the process of setting goals and policy agendas as actors rather than just delegates or representatives. Therefore, public administrators' efforts in promoting deliberation enhance self-governing capacities of both individuals and communities (Daly, 2003).

It is assumed that citizen participation is essential component of community development programs. Spiegel (1968) suggests that citizen participation is the process that can meaningfully tie programs to people by gaining citizens' support.

\subsection{Why Governments Use Citizen Participation as a Governance Tool}

In the literature, it is suggested that both citizens and governments benefit from citizen participation. Firs of all, citizen participation in the decision-making process can serve to check and 
Şahin, İ. (2014). Governance tools in public administration and emergent trends: Contracting, citizen participation, and networks. International Journal of Human Sciences, 11(2), 1082-1103. doi: 10.14687/ijhs.v11i2.2783

balance government activities, and reduce the likelihood that public administrators make arbitrary decisions.

It may create opportunities for citizens to shape government policies and programs, and provide citizens to play significant role in determining policy priorities (Lukensmeyer, 2006, p: 11). In addition, while some groups may have no influence on political agenda setting and decision making, others may have significant influence in shaping public policy making to serve their interests. This inequality often leads to injustice. Citizen participation can increase justice and uphold the rights of excluded and underserved citizens by incorporating their demands and interests into policy making process.

Citizen participation provides the citizens with information about important policy issues to help them understand the problem, alternative solutions, government policy options, and possible risks.

Providing information from citizens to public administrators, citizen participation can improve effectiveness of government decisions and policy implementations. Citizens may have experiential and local knowledge pertaining to some particular public problems and outcomes of the government policies. Therefore, they may help governments develop strategic and innovative programs (Fung, 2006, p: 73). For example, particularly in some public service areas such as education, human development, and public safety, citizen involvement may increase the quality of services by providing governments with feedbacks about the policies and information about their needs, priorities, and values.

By ensuring that citizens' concerns and demands are taken into account, citizen participation can legitimize government decisions, programs, and actions. Legitimate government policy means that it is supported by majority of the citizens. It is difficult for public administrators to achieve desired outcomes of the programs without public support. There may be conflict and disconnection between public administrators and citizens. Citizen participation can reduce conflict between public administrators and citizens by increasing trust (Fung, 2006, p: 22).

Citizen participation can increase citizen engagement and trust among citizens in the community. This increases capability of the community in finding solutions to its own problems by leveraging the energies and resources of individual citizens within the community (Lukensmeyer, 2006, p: 23). With this social capital, the citizens can understand group dynamics and interests of all community groups. In addition, the citizens can learn how to resolve conflicting interests for the overall welfare of the community and how to make changes they desire. 
Şahin, İ. (2014). Governance tools in public administration and emergent trends: Contracting, citizen participation, and networks. International Journal of Human Sciences, 11(2), 1082-1103. doi: 10.14687/ijhs.v11i2.2783

\subsection{Facilitating Citizen Participation}

There are some certain conditions that need to exist for citizen participation. People become more effectively involved in public policy issues when governments or public organizations provide following conditions (Wade, 1989). Participation can be facilitated by:

- Explaining the citizen the possible benefits to be gained.

- Stressing the obligation they have for improving the community.

- Providing the citizens with enough knowledge on the policy issues, situations, and possible consequences.

- Giving the assurance that their concerns and voices will be taken into account.

- Using crisis situations as a basis for providing citizen participation. This does not mean that crisis needs to be created; however, if it exists, it can be used as motivation for participation. For example, when drug abuse among youth becomes pervasive and a serious threat to the community, it is easier for the government to gain citizen involvement in shaping and implementing the drug control policy.

- Using appropriate form of participation for easily expressing their interests. People usually have limited time and resource to participate. Most of them are busy and do not have time. Considering these obstacles, the most appropriate form should be chosen to ease participation. For example, if the meeting place is too far from the town and scheduled at $09.00 \mathrm{AM}$ on Monday, citizens cannot be expected to participate because transportation would be a big problem and people would not have time in the business day.

There is a need to establish a participation mechanism in which citizens and public administrators can interact with each others and share their ideas regarding any public policy problem or project (Bryer, 2006; Bryer, 2008; Hummel \& Stivers, 1998). For example, this mechanism may be a kind of 'neighborhood councils' examined in the cases of Los Angeles Transportation and Public Works (Bryer, 2008) or may be an advanced form such as $21^{\text {st }}$ Century Town Meeting. Lack of these kinds of mechanism prevents participation of all relevant parties on the same table and increases the conflict by eroding the trust among them.

There are a number of citizen participation methods in the literature from City Neighborhood Councils to Citizen Assemblies. Some important participation methods are Citizen Jury, Deliberative Polling, Issue Forums, Study Circles, $21^{\text {st }}$ Century Town Meetings, and Citizen Assemblies (Lukensmeyer, 2006). 
Şahin, İ. (2014). Governance tools in public administration and emergent trends: Contracting, citizen participation, and networks. International Journal of Human Sciences, 11(2), 1082-1103. doi: 10.14687/ijhs.v11i2.2783

Table 1. Decision - Model for Public Participation

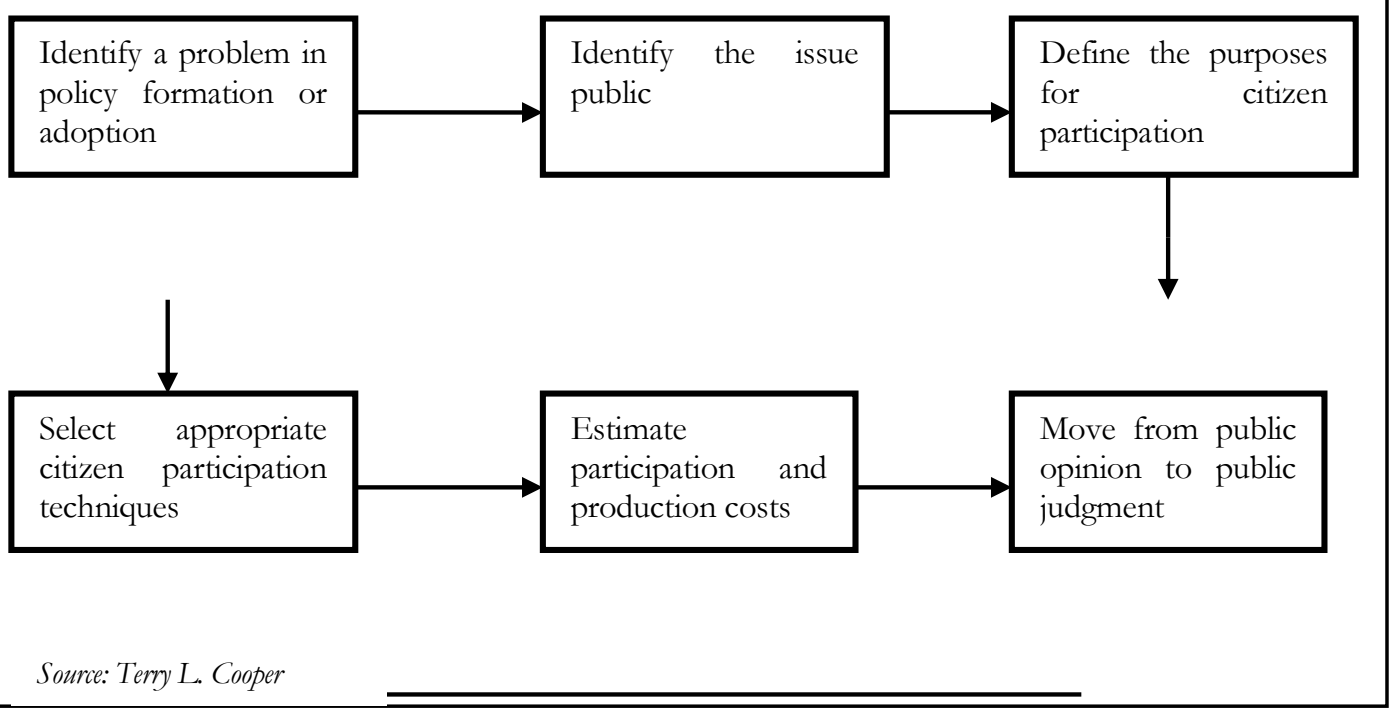

\subsection{Opposing Arguments for Citizen Participation}

Though citizen participation in governance is supported by the great majority of both the academicians and practitioners, there are some opposing arguments for the opinion that citizens should be more involved in all aspect of government decision-making.

Citizen participation may be too costly. Cost of citizen participation should be considered for both governments and citizens. The cost of transportation and time spent by the citizens are some of the costs to citizens. On the other hand, establishing and managing particularly the highvolume citizen participation process may be too costly for the public institutions and the governments.

There are always some certain types of policy issues that the governments cannot open the policy making process to the public. The policy issues such as national security and foreign policy need to be confidential and the governments do not want citizen involvement because of the security considerations and the national interests.

Citizen participation may be time consuming since it is always difficult to reach consensus with the large number of stakeholders or participants. Therefore, citizen involvement in policy making may negatively affect the effectiveness of decision making process because the decisions produce desired results only when they are made at the right time. 
Şahin, İ. (2014). Governance tools in public administration and emergent trends: Contracting, citizen participation, and networks. International Journal of Human Sciences, 11(2), 1082-1103. doi: 10.14687/ijhs.v11i2.2783

\subsection{Discussion and Implications for Public Administrators}

Citizens increasingly force the governments to play a more active role in involving citizens in decision making. Therefore, public administrators should not keep information on policy making or implementation in strict confidence and should be transparent as much as possible to citizens in the process. Sooner or later, the information regarding what is going on is known by the other parties or disclosed by anyone, then, this may lead to a more serious conflict between these stakeholders and get the things worse. Keeping some important information in confidence by leaving other actors out of the policy process may cause the process to go worse and made it more complicated. As a result, citizen participation is an essential tool to improve the quality and legitimacy of government activities (Bryer and Sahin, 2012).

There is a prevailing perception that public administrators who have specialized knowledge are the experts and they are more capable of handling public problems. Public administrators mostly think that only they know the best for the citizens' well-being. However, even if a public administrator is an expert on a particular issue regarding public service or policy, it is not sufficient for him to rely on only this expertise for policy making and implementation. This doctor-patient relationship metaphor should be changed. He should benefit from citizens' knowledge and combine his professional and administrative knowledge with citizens' experiential and lived knowledge (Bryer, 2008; Hummel \& Stivers, 1998; Stivers, 1994).

Another perception held by the citizens is that government activities are always inefficient and its bureaucratic components are not responsive to the citizens' concerns and interests, but rule bound and process oriented. Participatory process is the way to change this negative attitude and build mutual trust between public administrators and citizens. By providing citizen participation, on one hand, public administrators can view their work and the public problems through the eyes of ordinary citizens, on the other hand, ordinary people see how their own lives are connected with the others' and will be able to understand the importance of overall good of community (Stivers, 1994).

In the participation process, public administrators should not dominate, but facilitate the discussion. Policy parameters should be identified together. Participation process should encourage the citizens to work together and seek the solutions to their own problems.

Another challenge for public administrators to provide effective citizen participation is that the citizens who have more concerns and interests pertaining to a particular policy issue are more likely to be involved in the participation process. However, the possible consequences of the policy 
Şahin, İ. (2014). Governance tools in public administration and emergent trends: Contracting, citizen participation, and networks. International Journal of Human Sciences, 11(2), 1082-1103. doi: 10.14687/ijhs.v11i2.2783

to some extent may affect the lives of the other citizens as well. This leads to questions regarding equal participation and how well the citizens are represented by the participating representatives.

Public administrators may have various conflicting obligations. On one hand, they should be responsive to legislators and are constrained by procedural rules. On the other hand, they are supposed to run the organizations efficiently and effectively. These obligations may lead the public administrators to disregard citizen participation.

Citizen participation is important and necessary, but how feasible it is?

In the short term it may not look feasible in terms of efficiency because of the reasons mentioned above. However, in the long run, it can be said that building consensus on policy goals and implementations is more efficient because it helps to avoid ongoing conflict and achieve desired policy outcomes. In addition, depending on the nature of the policy issue, choosing the most appropriate form of participation is important for the public administrators to be able to adequately benefit from this governance tool. Neither the cost for the participating citizens nor the cost for public institutions should be too high.

Another tough question is; how much decision making authority should be shared with the citizens? Or who should make final decision? The answers to these questions will also contribute to the discussion on the deficiency of representative democracy.

Citizens should be more active participants in the policy process. However, if public administrators do not facilitate this participation by establishing appropriate participation tools, keeping these channels open, and promoting the citizens to be more active, it will not be possible for the citizens to be more active participants by themselves. Therefore, while public administrators need to be more active public administrators, citizens need to be more active citizens.

\section{Networks}

A number of scholars have offered various definitions of network. While some define networks as relations among individuals and groups, others define as structures of strategic relationships across organizations and markets. From the public administration perspective, the concept of network has often been used to describe the connections between the variety of actors involved in the delivery of services and the structures in which multiple organizations engage in partnership to address complex problems that single organization cannot cope with alone. This engagement includes sharing information, resources, and expertise (Agranoff and McGuire 2003; Goldsmith and Eggers 2004; O’Toole and Meier 2004; Milward and Provan 2000, 2003). 
Şahin, İ. (2014). Governance tools in public administration and emergent trends: Contracting, citizen participation, and networks. International Journal of Human Sciences, 11(2), 1082-1103. doi: 10.14687/ijhs.v11i2.2783

\subsection{Why Networks are needed}

Many reasons of why network is very important tool for governments can be suggested. Modern organizational environments are becoming more complex (Weick, 2001; Scott, 2001); thus, "uncertainty also increases, and the ratio of externally to internally induced changes also is increasing" (Kapucu, 2005 p. 36). Since many important problems are complex and interconnected, extensive collaboration among organizations is required. Therefore, forming interorganiaztional networks are considered as response to this complex and interdependent problems.

Many sociologists view network formation as driven by external factors such as social structure of resource dependence (Pfeffer \& Salanic, 1978). “Organizations create ties to manage uncertain environments and to satisfy their resource needs; consequently, they enter ties with other organizations that have resources and capabilities that can help them cope with these exogenous constraints" (Gulati \& Garguillo, 1999 p. 1440).

According to Gulati and Garguillo (1999), interdependence is the most common explanation for the formation of interorganizational cooperative ties. Organizations enter ties with other organizations in response to the problems created by the interdependencies that shape their common environment. Resource procurement and uncertainty reduction lead organizations to be dependent on others in their environment. These are essential for organizations to pursue their goals. Interorganizational networks provide organizations to manage their dependence on other organizations in their environment and mitigate the uncertainty generated by this dependence. Therefore, the higher the interdependence between two organizations, the higher their incentive to combine their resources and capabilities through an interorganziational cooperative tie (Gulati \& Garguillo, 1999).

It can be said that some changes in traditional public administration approach have increased the importance of utilization of network in public administration. First of all, it is obvious that government is no longer the only actor having enough resources, expertise, and information to solve all public problems since today's problems have become so complicated that only government agencies cannot cope with. Public organizations need to incorporate the resources, knowledge, and expertise of private and non-profit actors into examining problems, developing strategies, and producing solutions to public problems. Over the past two decades, contracting has been increasingly used by governments to improve its effectiveness. This new trend has made the public administrators the partners with the representatives of other sector organizations in some public policy making and implementation. In the network context, governments play more of steering, promoting, and regulating roles. While some networks may consist of the organizations 
Şahin, İ. (2014). Governance tools in public administration and emergent trends: Contracting, citizen participation, and networks. International Journal of Human Sciences, 11(2), 1082-1103. doi: 10.14687/ijhs.v11i2.2783

from single sector such as public, others may be cross-sectoral networks consisting of the ones from different sectors such as public, private, and non-profit (Sahin and Gozubenli, 2014).

Table 2. Hierarchical and Network Approaches to Public Administration

\begin{tabular}{|l|c|c|}
\hline Features & Hierarchy & Network \\
\hline Normative Basis & Employment Relationship & Complementary Strengths \\
\hline $\begin{array}{l}\text { Means of } \\
\text { Communication }\end{array}$ & Routines & Relational \\
\hline $\begin{array}{l}\text { Methods of Conflict } \\
\text { Resolution }\end{array}$ & $\begin{array}{c}\text { Administrative-fiat; } \\
\text { Supervisory }\end{array}$ & $\begin{array}{c}\text { Norm of reciprocity; } \\
\text { Reputation concerns }\end{array}$ \\
\hline Degree of Flexibility & Low & Medium \\
\hline $\begin{array}{l}\text { Amount } \\
\text { Commitment }\end{array}$ & Medium to High & Medium to High \\
\hline Tone or Climate & Formal, bureaucratic & Open-ended, mutual \\
benefits
\end{tabular}

Source: Powell, $W . W .(1990)$.

Private, non-profit and government organizations all play significant roles in the public policy making and implementation (Milward \& Provan, 2000). Particularly delivering some public services such as health services requires partnership and integration of the organizations coming from these different sectors. Each member organization contributes to the partnership by using their advantages coming from being in different sectors. In the Every Child Succeeds program of Cincinnati, to improve maternal and infant health, a network structure was established among public, private, and non-profit organizations such as United Way, private hospitals, and Heath Departments by bringing them together for a common purpose. For example, in this process, the program benefited from using private sector experiences such as corporate quality improvement tools (strict performance measurement, data collection, creating action plan for each agency, etc.) (Quest for Community Health, 2002).

In this article, the term network is used to define multiple-organizational relations involving multiple nodes of interactions. This network type contains a group of organizations which 
Şahin, İ. (2014). Governance tools in public administration and emergent trends: Contracting, citizen participation, and networks. International Journal of Human Sciences, 11(2), 1082-1103. doi: 10.14687/ijhs.v11i2.2783

exchange information, and engage in joint activities. Organizations, in the network, organize themselves by maintaining their individual autonomy.

Some important incidents trigger communication and interaction among organizations that lead to collective action. Significant events increase density of communication and interaction among organizations and facilitates emergence of new networks among different organizations because it is difficult or even impossible for an organization to cope with these problems alone (Kapucu, 2005).

The common problem that many agencies face leads them to cooperate with each other and create an interorganiational network. The most popular example to this assumption is September 11 attacks. These attacks have forced many government agencies, particularly security agencies, to involve in more cooperative actions and be aware of the importance of information sharing. Several regional information sharing networks emerged in which local law enforcements agencies participated. In addition, at the federal level, policy makers and top leaders emphasized the lack of coordination and cooperation between intelligence agencies and attempted to solve these problems by creating common information sharing mechanisms and networks. For example, the Joint Regional Information Exchange System (JRIES) has been established by the Department of Homeland Security in 2004 to exchange information with other local and federal law enforcement agencies.

There are a number of barriers to information sharing among the agencies. Interorganizational networks can help the agencies eliminate some of these barriers by creating clearly defined information sharing channels and procedures, decreasing the cost of IT infrastructure for each agency and negative effect of different organizational cultures, providing communication and, to some extent, increasing trust between the agencies, and reducing intensity of 'turf war' between the agencies. Despite these potential advantages, it is possible for the networks to experience serious problems originated from the network system itself.

In the literature, a number of classification regarding network types have been made by the scholars. While some categorizations are based on the functions of networks (Service Implementation Networks, Information Diffusion Networks, Problem Solving Networks, and Community Capacity Building Networks), others focus on classifying the networks according to their governance types (Self-Governance, Lead Organization, and Network Administrative Organization) (Milward and Provan, 2006) 
Şahin, İ. (2014). Governance tools in public administration and emergent trends: Contracting, citizen participation, and networks. International Journal of Human Sciences, 11(2), 1082-1103. doi: 10.14687/ijhs.v11i2.2783

Which network model is the most appropriate depends on many different variables such as the characteristics of the agencies and the problems to be solved. For example, regarding information sharing problem between intelligence and law enforcement agencies, centrally coordinated information network model in which agencies maintain their independence and autonomy can be more appropriate (Sahin and Matusitz, 2013). In this model, the network system consisting of regional centers and a central hub can provide effective flow of information between the agencies both at national and local level.

\subsection{Benefits of Networks}

Using the tool of network, public organizations can:

- reduce possible risk and cost by sharing with other stakeholders and combining resource that they themselves do not possess.

- have ability to access skills, resources, expertise, knowledge, and information.

- learn the new ways to produce and provide services since networks foster collaborative learning and using innovative techniques.

- benefit from flexibility and adaptability of the network structures. Networks tend to be more flexible since networks are non-coercive structures and organizational boundaries are less clear among the member organizations.

- be more effective to respond complex service demands such as health services and emergency management.

\subsection{Challenges in Networks}

Governments are likely to face some challenges originated from the nature of networks. It is more difficult to coordinate network structures than hierarchic structures since networks consist of multiple organizations coming from different organizational cultures or different sectors. It is not possible to manage the networks with command and control approach. It may be time consuming to form any kind of network for addressing public problems since it is not easy task to bring different organizations pursuing their own interests together and convince them to focus on a common goal. Another challenge is that resolving conflict between organizations in the network is difficult. Therefore, playing negotiating role is essential for the public administrators dealing with networks. Furthermore, low stability of network structures is considered as one of the main limitations. For example, turnover and disengagement of organizations may create disruptions during long-term networks. Finally, difficulty in measuring network effectiveness is another 
Şahin, İ. (2014). Governance tools in public administration and emergent trends: Contracting, citizen participation, and networks. International Journal of Human Sciences, 11(2), 1082-1103. doi: 10.14687/ijhs.v11i2.2783

important challenge. Existence of multiple organizations playing diverse roles makes network evaluation more complicated. This evaluation problem also negatively affects the accountability of the organizations since it is difficult to decide which organization makes desired contribution to the network effort. On the other hand, it is not easy to evaluate overall effectiveness of the network as well. Where does one need to look at to evaluate whether a network performs well?

\subsection{Discussion and Implications for Public Administrators}

Network is one of the newest and the most widely used governance tools; however, it cannot be said that it is the most promising one. In the past, there were a lot of failed attempts at network building. For example, the failure of post-Katrina evacuation plan in New Orleans demonstrated that coordinating public and private organizations in the network was essential for successful networks (Keifer and Montjoy, 2006).

To effectively utilize the tool of network, public administrators, first of all, should understand that they are not the only actors having dominant power and authority in the network structures. They should consider the other actors from different organizations and sectors as the partners in the network process.

Public administrators should know the importance of governance structure of any network. Participants must realize the importance of the rules governing their relationship with each others to be able to jointly make decisions since creating governance structure will allow them to solve the problem of collective action and reconcile the organizational self-interest and collective-interests in the network (Thomson \& Perry \& Miller, 2007; Sahin and Matusitz, 2013). Balancing between overall network objectives and the interests of the individual organizations is one of the basic jobs for the public administrators within the network.

Networks are more likely to be effective when networks and relationships among member organizations are well coordinated and governed. The role of mechanism that coordinates, supports network operations, and provides communication is important for managing conflict and highperformance network structures (Provan and Milward, 2000; Sahin and Matusitz, 2013). It is easier for the well-coordinated networks to resolve possible conflicts among the members. Clearly defined roles and responsibilities of each member organization can help the networks cope with coordination problems.

Adequate funding is another important requirement for successful network. According to Provan and Milward (2000), besides having stability and network coordination mechanism, networks need well funding and they suggest that a network is more likely to be effective when it is 
Şahin, İ. (2014). Governance tools in public administration and emergent trends: Contracting, citizen participation, and networks. International Journal of Human Sciences, 11(2), 1082-1103. doi: 10.14687/ijhs.v11i2.2783

well and directly funded. Networks in resource-rich environment are more likely to be effective. Well funding is a significant requirement particularly for the networks performing in delivering public health service because of its high cost. In the Every Child Succeeds program of Cincinnati, multiple sources such as United Way, Medicaid, and the others made significant contributions to the success of the program by funding it. (Quest for Community Health, 2002)

It is essential for public administrators to have reliable and accurate performance measurement to be able to evaluate how effective the network is at the levels of organization, network, and community (Provan and Milward, 2001).Evaluating both the performance of the participating organizations and the success of the network as a whole are essential for the network to make needed changes and measure the extent to which the program achieves the predetermined outcomes. For this evaluation, clear performance criteria, measures, and indicators should be identified. In addition, the data pertaining to these indicators should be systematically and accurately collected. The data collection and evaluation process allows us to understand whether the network is working effectively or not and which parts of it are properly working (Quest for Community Health, 2002).

\section{Conclusion}

Contemporary public policy problems are complex and require a new public administration approach. Public organizations need to interact with many actors from different sectors because they need contributions of the other actors to effectively deliver public services. In this concept, conflicting interests, ideas, and operating practices of each parties need to be managed properly throughout the process to achieve desired policy outcomes. Public administrators and legislators are no longer the only actor in public policy making and policy implementation. In public administration, making good law and appointing experts or talented officials does not guarantee the success in public problem solving. The involvement of other parties such as citizens and private companies is an essential component of this new approach.

While the tool of contracting is used to increase efficiency, improve quality of public services, and access expertise not available in-house; the tool of citizen participation is used to enhance legitimacy, facilitate public programs, and achieve policy outcomes. In this environment in which diverse and multiple actors exist; network structure is the most appropriate tool for the public administrators to govern the relationships between public, private, non-profit organizations, and citizens. 
Şahin, İ. (2014). Governance tools in public administration and emergent trends: Contracting, citizen participation, and networks. International Journal of Human Sciences, 11(2), 1082-1103. doi: 10.14687/ijhs.v11i2.2783

Public administrators should not act as the only problem solver, but they should be facilitators in collaborative problem solving to mobilize the citizens for finding solution to their own problems. They need to learn to listen to the citizens because their insights, perspectives, and values are important. However, government organizations remain core actors in the process of citizen participation and network because the primary responsibility is taken by the government. Government cannot transfer its legitimacy to other actors. Similarly, in contracting, public administrators do not diminish their responsibility by paying contractor firms to do the work.

\section{References}

Abrahamson, M. A., \& Breul, J.D., \& Kamensky, J.M (2006). Six Trends Transforming Government. IBM Center for the Business of Government.

Agranof, R. \& McGuire, M. (2003). Collaborative Public Management: New Strarategies for Local Governments. Washington, DC: Georgetown University Press.

Agranoff, R. (2003). Leveraging Networks: A Guide for Public Managers Working Across Organizations. Washington, DC: IBM Center for the Business of Government.

Blondal, J. (2005). International Experience Using Outsourcing, Public-

Private Partnerships \& Vouchers. Washington, DC: IBM Center for the Business of Government.

Bryer, T. T. \& Sahin, I. (2012). Administrators as Deliberative Representatives: A Revised Public Service Role. International Journal of Public Administration, 35(14), 925-933.

Bryer, T. A. (2008). Warning: The Hollow State can be deadly. Public Administration Review, May/June 2008.

Bryer, T. A. (2009). Explaining responsiveness in collaboration: Administrator and citizen role perceptions. Public Administration Review, 69(2), 271-283.

Bryer, T. A. (2007). Toward a relevant agenda for a responsive public administration. Journal of Public Administration Research and Theory, 17(3), 479-500.

Daly, M. (2003). Governance and Social Policy. Journal of Social Policy, 32(1), 113-128.

Eggers, W. \& Goldsmith, S. (2004). Government by Network: The New Public Management Imperative. Retrieved on November 12, 2008 from www.deloitte.com/research (2007).

Eggers, W., \&Goldsmith, S. (2003). Networked Government. Government Executive, June 2003. Retrieved on September 13, 2008 from http://www.manhattaninstitute.org/pdf/gov exec 6-03.pdf

Fung, A. (2006). Varieties of participation in complex governance. Public administration review, 66(1), 66-75.

Group Health Community Foundation (2002). Quest for Community Health: Lessons on Improving Health from Nine California Communities. Retrieved on November 12, 2008 from http://www.ghcfoundation.org/downloads/ghcf-publication-quest-comm-health-hiireport-2002.pdf. 
Şahin, İ. (2014). Governance tools in public administration and emergent trends: Contracting, citizen participation, and networks. International Journal of Human Sciences, 11(2), 1082-1103. doi: 10.14687/ijhs.v11i2.2783

Gulati, R., \& Gargiulo, M. (1999). Where do interorganizational networks come from? 1. American journal of sociology, 104(5), 1439-1493.

Herrera, R. (2004). Good Governance against Good Government? Retrieved on September 13, 2008 from http://www.alternatives.ca/article1144.html

Hummel, R. P., \& Stivers, C. (1998). Government Isn't Us: The Possibility of Democratic Knowledge in Representative Government. In Cheryl Simrell King \& Camilla Stivers (Eds.), Government Is Us: Public Administration in an Anti-Government Era. Thousands Oaks, CA: Sage Publications.

Kapucu, N. (2005). Interorganizational Coordination in Dynamic Context: Networks in Emergency Response Management Connections 26(2), 33-48. Retrieved from http:/ /www.insna.org/Connections-Web/Volume26-2/4.Kapucu.pdf.

Kiefer, J. J., \& Montjoy, R. S. (2006). Incrementalism before the storm: Network performance for the evacuation of New Orleans. Public Administration Review,66(s1), 122-130.

Kelman, S. J. (2002). Contracting. In Lester M. Salamon (ed.), The Tools of Government: A Guide to the New Governance, 282-318, New York, NY: Oxford University Press.

Lawther, W. C. (2003). Contracting for the 21st century: A partnership model.The procurement revolution, 167-216. Retrieved on November, 15, 2008 from www. endowment.pwcglobal.com.

Lukensmeyer, C. \& Torres, L. H. (2006). Public Deliberation: A Manager's Guide to Citizen Deliberation. Washington, DC: IBM Center for the Business of Government.

Martin, L.L. (2002). Making Performance-Based Contracting Perform:

What the Federal Government Can Learn from State \& Local Governments. Washington, DC: IBM Center for the Business of Government.

Martin, L. L. (2001). "Designing Alternative Service Delivery Options."

Paper presented at the Guarantor Government Workshop on Alternative Service Delivery Options for Local Government, Taby, Sweden, June.

Martin, L. L. (1999). Public-Private Competition: A Public Employee Alternative to Privatization. Review of Public Personnel Administration, 19(1), 59-70.

Mills, A. \& Broomberg, J. (1998). Experiences of contracting: An overview of the literature. Macroeconomics, Health and Development Series. Technical Paper No. 33. World Health Organisation. Geneva.

Milward, B. A., \& Provan, K. G. (2000). Governing the Hollow State. Journal of Public Administration Research and Theory, 10(2), 359-379.

O’Toole, L. J., \& Meier, K. (2004). Public Management in Intergovernmental Networks: Matching Structural Networks and Managerial Networking. Journal of Public Administration Research and Theory 14(4), 469-494.

Pfeffer, J. \& Salancik, G. (1978). The External Control of Organizations. New York.

Powell, W. W. (1990). Neither market nor hierarchy: Network forms of organization. Research in Organizational Behavior, 12, 295-336.

Policy Consensus Initiative (PCI). (2006). Legislators at a Crossroads: Making Choices to Work Differently. Retrieved on November 10, 2008 from http://www.policyconsensus.org/publications/reports/docs/Crossroads.pdf 
Şahin, İ. (2014). Governance tools in public administration and emergent trends: Contracting, citizen participation, and networks. International Journal of Human Sciences, 11(2), 1082-1103. doi: 10.14687/ijhs.v11i2.2783

Provan, K. G. \& Milward, H. B. (2006). A Manager's Guide to Choosing and Using Collaborative Networks.IBM Center for The Business of Government. Rterieved in November 2, 2008 from http://www.businessofgovernment.org/pdfs/ProvanReport.pdf

Provan, K. G. \& Milward, H. B. (2001). Do Networks Really Work? A Framework for Evaluating Public Sector Organiational Networks. Public Administration Review, 61(4), 414-424.

Reddel, T. (2002). Beyond Participation, Hierarchies, Management, and Markets: New Governance and Place Policies. Australian Journal of Public Administration, 61(1), 50-63.

Sahin, I. \& Gozubenli, M. (2014). Cross-Sectoral Governance: Examining the Florida Integrated Network For Data Exchange And Retrieval (Finder). European Scientific Journal, 10(1).

Sahin, I. \& Matusitz, J. (2013) Using Network Theory to Improve Outcomes for Drug Law Enforcement Agencies. Journal of Policy Practice, 12(2), pp. 125-142.

Scahill, J. (2007). The Rise of the World's Most Powerful Mercenary Army. New York: Nation Books.

Scott, W. R. (2001). Organizations: Rational, Natural, and Open Systems. Englewood Cliffs, NJ: PrenticeHall.

Sehested, K. (2003). Cross-Sector Partnerships as a New Form of Local Governance. In Louise Kjaer (Ed.), Local Partnerships in Europe: An Action Research Project, The Copenhagen Centre.

Spiegel, H. B.C. (1968). Citizen Participation in Urban Development. Washington, D.C.: N\&L Institute for Applied Behavioral Science.

Stivers, C. (1994). The Listening Bureaucrats: Responsiveness in Public Administration. Public Administration Review, 54(4), 364-369.

Thomson, A. M. \& Perry, J. L. \& Miller, T. K. (2007). Conceptualizing and Measuring Collaboration. Journal of Public Administration Research and Theory, published online on December 2007. 1, Retrieved from http://ipart.oxfordjournals.org/cgi/content/abstract/mum036v1

Wade, J. (1989). Felt Needs and Anticipatory Needs: Reformulation of a Basic Community Development Principle. Journal of the Community Development Society (20), 116-123

Weick, K. E. (2001). Making Sense of the Organization. Oxford, Massachusetts: Blackwell Business. 